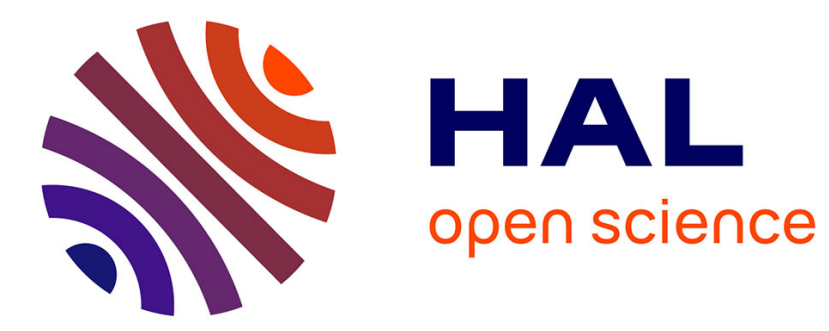

\title{
Design of asymptotic preserving schemes for the hyperbolic heat equation on unstructured meshes
}

Christophe Buet, Bruno Després, Emmanuel Franck

\section{To cite this version:}

Christophe Buet, Bruno Després, Emmanuel Franck. Design of asymptotic preserving schemes for the hyperbolic heat equation on unstructured meshes. Numerische Mathematik, 2012, http://www.springer.com/alert/urltracking.do?id=Lbe18b9M9c40acSaff211f. $\quad$ 10.1007/s00211-0120457-9 . hal-00523809

\section{HAL Id: hal-00523809 \\ https://hal.science/hal-00523809}

Submitted on 6 Oct 2010

HAL is a multi-disciplinary open access archive for the deposit and dissemination of scientific research documents, whether they are published or not. The documents may come from teaching and research institutions in France or abroad, or from public or private research centers.
L'archive ouverte pluridisciplinaire HAL, est destinée au dépôt et à la diffusion de documents scientifiques de niveau recherche, publiés ou non, émanant des établissements d'enseignement et de recherche français ou étrangers, des laboratoires publics ou privés. 
